\title{
White blood cells, C-reactive protein and erythrocyte sedi- mentation rate in pneumococcal pneumonia in children
}

\author{
M. Korppi*, T. Heiskanen-Kosma*, M. Leinonen**
}

White blood cells, $C$-reactive protein and erythrocyte sedimentation rate in pneumococcal pneumonia in children. M. Korppi, T. Heiskanen-Kosma, M. Leinonen. ( $E R S$ Journals Ltd 1997.

ABSTRACT: We evaluated the applicability of C-reactive protein (CRP), erythrocyte sedimentation rate (ESR), white blood cell count (WBC), and absolute neutrophil count (ANC), in the screening of pneumococcal (PNC) pneumonia in children.

In 1981-1982, 161 children were treated for radiologically verified communityacquired pneumonia in the hospital during a period of 12 months. The Streptococcus pneumoniae aetiology of infection was studied by antigen, antibody and immune complex assays in acute and convalescent sera. In acute blood samples, CRP was measured by the immunonephelometric method, ESR by the Westergren method, WBC using an automatic cell counter, and thereafter the ANC was calculated after microscopic examination of peripheral smears.

CRP and ESR were significantly higher in patients with alveolar $(n=53)$ than in those with interstitial $(n=108)$ pneumonia. CRP, ESR and ANC were significantly higher in PNC $(n=29)$ than in viral $(n=23)$ pneumonia. The values in mixed PNC and viral infections $(n=17)$ were approximately midway between $P N C$ and viral cases. All cases with serologic evidence of $S$. pneumoniae aetiology were combined $(n=46)$ for calculation of diagnostic parameters. When a cut-off limit of $60 \mathrm{mg} \cdot \mathrm{L}^{-1}$ was used, CRP had a sensitivity of $26 \%$ and a specificity of $83 \%$ in the screening of PNC pneumonia.

We conclude that $\mathrm{C}$-reactive protein and erythrocyte sedimentation rate have a limited capacity to differentiate between pneumococcal and nonpneumococcal pneumonia. C-reactive protein is recommended as the first-line method of screening, and the value of $60 \mathrm{mg} \cdot \mathrm{L}^{-1}$ as the cut-off limit.

Eur Respir J 1997; 10: 1125-1129.

\author{
*Dept of Pediatrics, Kuopio University \\ Hospital, Finland. **National Public Health \\ Institute, Oulu, Finland.
}

Correspondence: M. Korppi

Dept of Pediatrics

Kuopio University Hospital

FIN-70210 Kuopio

Finland

Keywords: C-reactive protein erythrocyte sedimentation rate pneumococcal infection pneumonia

white blood cells

Received: September 191996 Accepted after revision January 261997
Differentiation between viral and bacterial pneumonia, if possible, would be of utmost importance for clinicians. In young children, the most important problem is how to differentiate between pneumonias caused by respiratory viruses or Streptococcus pneumoniae [1, 2]. Moreover, mixed infections caused by viruses and bacteria, especially by respiratory syncytial virus (RSV) and pneumococci (PNC), are common [3]. Since the assessment of the specific microbial aetiology of pneumonia is difficult, nonspecific inflammatory parameters and the type of infiltration in a chest radiograph are widely used for this purpose. In children, serum C-reactive protein (CRP) appears to be more useful than the conventionally used parameters, white blood cell count (WBC) or erythrocyte sedimentation rate (ESR) [4, 5]. The absolute neutrophil count (ANC) is usually elevated in bacteraemic infections [6]. An alveolar infiltrate is used as evidence of bacterial, and an interstitial infiltrate as evidence of viral or mycoplasmal pneumonia [7,8]. There are no previous studies on the diagnostic efficacy of these nonspecific parameters in pneumococcal pneumonia.

We have previously published our results concerning $\mathrm{CRP}, \mathrm{WBC}$ and $\mathrm{ANC}$ in a heterogeneous group of over
200 children with different viral and bacterial respiratory infections $[9,10]$. The purpose of the present study was to determine the diagnostic value of CRP, WBC, ANC and ESR in a more homogenous group, of 161 children with pneumonia, with special reference to $S$. pneumoniae aetiology. PNC aetiology was assessed by means of two antigen, three antibody and three immune complex assays. Measurement of immune complexes is a relatively new diagnostic method for pneumococcal pneumonia [11].

\section{Materials and methods}

In the course of a prospective study in 1981-1982, 195 children were treated for presumed pneumonia in the Department of Pediatrics, Kuopio University Hospital, Finland [2]. The diagnosis of pneumonia was based on the presence of pulmonary infiltration on a chest radiograph, as evaluated by two radiologists without knowledge of the clinical findings. In this radiological evaluation, 161 cases were classified as definite pneumonia; the type being alveolar in 53 cases and interstitial in 108 . Forty six of the children were infants less than 12 
months old, 46 were $12-23$ months, 37 were $2-4$ years, and 32 were 5-15 yrs of age.

The viral aetiology was studied by using antibody assays in paired sera and antigen assays in nasopharyngeal aspirates for respiratory viruses, including respiratory syncytial virus (RSV), parainfluenza 1, 2 and 3 virus, influenza $\mathrm{A}$ and $\mathrm{B}$ virus, and adenoviruses [2]. A viral infection was diagnosed in 54 cases: RSV was identified in 42, parainfluenza virus in three, and adenoviruses in nine cases.

The pneumococcal aetiology was studied by antigen assays in acute serum and urine [2], by antibody assays to capsular C-polysaccharide (C-PS), to type-specific capsular polysaccharides (CPS), and to a protein antigen, pneumolysin (PNL), in paired sera [2]; and in 1995 , by immune complex assays in acute and convalescent sera, measuring circulating complexes containing C-PS, CPS or PNL immunoglobulin $\mathrm{M}$ (IgM) (to PNL) or immunoglobulin $\mathrm{G}$ ( $\operatorname{IgG}$ ) (to all three antigens) antibodies by enzyme immunoassay (EIA). The method, with minor modifications, was the same as described previously [11]. The methods have been validated in healthy children, and the diagnostic criteria were as follows: the presence of PNC antigen in acute serum or urine $[2,3]$; a threefold or greater rise in $\operatorname{IgM}$ or $\operatorname{IgG}$ antibodies to C-PS or CPS in paired sera [2, 12, 13]; a twofold or greater rise in IgG antibodies to PNL in paired sera [2, 14]; or the presence of immune complexes in either acute or convalescent serum [15]. The antigen assays were positive in 15 cases, antibody assays in 22 cases, and immune complex assays in 28 cases. Based on combined serological data, an S. pneumoniae aetiology was indicated in 55 cases $(32 \%)$.

In addition, antibodies were measured to Haemophilus influenzae, Branhamella catarrhalis, Mycoplasma pneumoniae and Chlamydia spp. in paired sera, as described previously [2]. Based on serological evidence, one or more of these bacteria caused 23 (14\%) infections; $H$. influenzae was demonstrated in 13 cases; B. catarrhalis in three; M. pneumoniae in two; and Chlamydia spp. in eight cases. A mixed infection with PNC was seen in four cases, with viruses in nine, and with both PNC and viruses in five. These 23 patients were excluded from the aetiological analysis of the present study.

Finally, the aetiological groups were as follows: PNC infection alone in 29 cases; mixed PNC-viral infection in 17 cases; and viral infection alone in 23 cases. The number of patients with no aetiological findings was 69 .

Nonspecific inflammatory parameters, including WBC, ANC, CRP and ESR were determined in acute blood samples obtained on admission. Total WBCs were determined by an automatic cell counter. The differentials of WBC were studied by microscopic examination of peripheral smears, and thereafter, the ANC was calculated [10]. Serum CRP concentration was measured by the immunonephelometric method, and ESR by the Westergren method [9].

The Chi-squared test, with a correction devised by Yates, the two-tailed t-test, and the statistics with confidence intervals, were used in the analysis of the data. The diagnostic parameters, such as sensitivity, specificity, and positive and negative predictive values, were calculated using routine equations. A p-value less than 0.05 was considered statistically significant.

\section{Results}

The association between the type of infiltration, alveolar or interstitial, and the values of WBC, ANC, CRP or ESR were studied in a total of 161 children with radiologically verified pneumonia (table 1). CRP and ESR were significantly higher in patients with alveolar than in those with interstitial pneumonia. The $95 \%$ confidence intervals (95\% CI) also completely separated these two groups. In contrast, no significant differences were observed between the groups in $\mathrm{WBC}$ or ANC results. The WBC, ANC, CRP and ESR results were also analysed in different age groups. They were significantly lower in infants than in children over 1 year old, but above that age no dependence was present between age and any of the parameters (data not shown).

The associations between the aetiology of infection, PNC, viral or mixed PNC-viral, and the values of WBC, ANC, CRP and ESR, were studied in the 69 children with serologically verified PNC or viral infection (table $2)$. There was a wide variation of values within each aetiological group. The values were highest in the children with PNC infection, and lowest in the children with viral infection. In mixed PNC-viral infections the values were approximately midway between PNC and viral cases. The CRP, ESR and ANC results differed significantly between PNC and viral infections (table 2). Moreover, these two groups were almost completely separated by the $95 \%$ CI. ANC results differed significantly between children with PNC and mixed PNC-viral infections; no other differences between PNC and mixed cases, or between mixed and viral cases, were found. The CRP, ESR, WBC or ANC values were somewhat higher when PNC aetiology was indicated by antibodies, as compared to antigen or immune complex positive cases; however, the differences were not significant (data not shown).

For the parameters measured, the mean (SD) values in the 69 patients with unknown aetiology were: CRP 29.3 (35.1) $\mathrm{mg} \cdot \mathrm{L}^{-1}$; ESR 22.6 (15.9) $\mathrm{mm} \cdot \mathrm{h}^{-1}$; WBC 13.7 (4.9) $\times 10^{9}$ cells $\cdot \mathrm{L}^{-1}$; and ANC 8.9 (4.9) $\times 10^{9}$ cells $\cdot \mathrm{L}^{-1}$. CRP $(\mathrm{p}<0.01)$ and ESR $(\mathrm{p}<0.001)$ differed significantly from those in PNC infections.

The upper limits of the $95 \%$ CIs of CRP $\left(60 \mathrm{mg} \cdot \mathrm{L}^{-1}\right)$, ESR $\left(35 \mathrm{~mm} \cdot \mathrm{h}^{-1}\right)$, WBC $\left(15 \times 10^{9}\right.$ cells $\left.\cdot \mathrm{L}^{-1}\right)$ and ANC

Table 1. - White blood cell count (WBC), absolute neutrophil count (ANC), C-reactive protein (CRP) concentration and erythrocyte sedimentation rate (ESR) in 53 children with alveolar and 108 children with interstitial pneumonia

\begin{tabular}{lccc}
\hline & \multicolumn{2}{c}{ Type of pneumonia } & \\
\cline { 2 - 3 } Parameters & $\begin{array}{c}\text { Alveolar } \\
(\mathrm{n}=53)\end{array}$ & $\begin{array}{c}\text { Interstitial } \\
(\mathrm{n}=108)\end{array}$ & p-value \\
& $15.4 \pm 7.3$ & $13.1 \pm 5.5$ & $\mathrm{NS}$ \\
$\mathrm{WBC}$ & $(13.4-17.4)$ & $(12.0-14.2)$ & \\
$\times 10^{9}$ cells $\cdot \mathrm{L}^{-1}$ & $9.8 \pm 6.6$ & $8.3 \pm 5.2$ & $\mathrm{NS}$ \\
$\mathrm{ANC} \times 10^{9} \mathrm{cells} \cdot \mathrm{L}^{-1}$ & $(7.9-11.7)$ & $(8.3-9.4)$ & \\
& $76.0 \pm 86.2$ & $31.6 \pm 36.3$ & $<0.001$ \\
$\mathrm{CRP} \mathrm{mg} \cdot \mathrm{mL}^{-1}$ & $(52.3-101.5)$ & $(24.6-38.6)$ & \\
& $43.7 \pm 30.0$ & $25.5 \pm 18.8$ & $<0.001$ \\
ESR $\mathrm{mm} \cdot \mathrm{h}^{-1}$ & $(35.4-52.0)$ & $(21.9-29.1)$ & \\
& & & \\
& & &
\end{tabular}

Values are presented as mean \pm SD, and $95 \%$ confidence intervals in parentheses. NS: nonsignificant. 
Table 2. - White blood cell count (WBC) and absolute neutrophil count (ANC), C-reactive protein (CRP) concentration and erythrocyte sedimentation rate (ESR) in relation to the aetiology of infections in the 69 children with pneumonia and serologically indicated pneumococcal or viral aetiology

\begin{tabular}{|c|c|c|c|c|c|}
\hline \multirow[b]{2}{*}{ Parameters } & \multicolumn{5}{|c|}{ Aetiological group of infection } \\
\hline & $\begin{array}{l}\text { Pneumococcal } \\
(\mathrm{n}=29)\end{array}$ & p-value & $\begin{array}{l}\text { Mixed"\# } \\
(\mathrm{n}=17)\end{array}$ & $p$-value & $\begin{array}{l}\text { Viral } \\
(\mathrm{n}=23)\end{array}$ \\
\hline WBC $\times 10^{9}$ cells $\cdot \mathrm{L}^{-1}$ & $\begin{array}{c}16.2 \pm 8.1 \\
(13.4-19.0)\end{array}$ & NS & $\begin{array}{l}12.8 \pm 6.0 \\
(10.0-15.6)\end{array}$ & NS & $\begin{array}{l}12.3 \pm 8.1 \\
(9.5-15.1)\end{array}$ \\
\hline ANC $\times 10^{9}$ cells $\cdot \mathrm{L}^{-1}$ & $\begin{array}{l}13.4 \pm 7.3 * \\
(8.7-13.7)\end{array}$ & $<0.05$ & $\begin{array}{c}6.4 \pm 3.6 \\
(4.7-8.1)\end{array}$ & NS & $\begin{array}{c}7.0 \pm 5.9 \\
(4.4-9.6)\end{array}$ \\
\hline $\mathrm{CRP} \mathrm{mg} \cdot \mathrm{L}^{-1}$ & $\begin{array}{c}89.9 \pm 102.0 * \\
(53.9-126.0)\end{array}$ & NS & $\begin{array}{c}51.2 \pm 61.8 \\
(21.4-81.0)\end{array}$ & NS & $\begin{array}{c}40.9 \pm 48.8 \\
(21.5-60.3)\end{array}$ \\
\hline ESR $\mathrm{mm} \cdot \mathrm{h}^{-1}$ & $\begin{array}{l}42.8 \pm 34.8^{*} \\
(32.0-54.8)\end{array}$ & NS & $\begin{array}{c}34.3 \pm 21.9 \\
(24.4-44.2)\end{array}$ & NS & $\begin{array}{c}29.4 \pm 15.3 \\
(23.4-35.4)\end{array}$ \\
\hline
\end{tabular}

Values are presented as mean $\pm \mathrm{SD}$, and $95 \%$ confidence intervals in parentheses. $*$ : $\mathrm{p}<0.05$ vs patients with viral infection alone. \#: the viruses were RSV in 14 cases, parainfluenza in one, and adenovirus in three cases, including one dual virus infection; $¥$ : the viruses were RSV in 28 cases, parainfluenza in two, and adenovirus in two cases, including no dual virus infections. NS: nonsignificant; RSV: respiratiory syncytial virus.

$\left(10 \times 10^{9}\right.$ cells $\left.\cdot \mathrm{L}^{-1}\right)$ in the cases of viral pneumonia with no PNC involvement were tested as screening limits between PNC and non-PNC pneumonia (table 3). In this analysis, the cases with PNC aetiology, whether single or mixed, were combined with the group of PNC pneumonia, and viral cases and cases with unknown aetiology were combined with the group of non-PNC pneumonia. For CRP, sensitivity was $26 \%$, specificity $83 \%$, positive predictive value $43 \%$ and negative predictive value $76 \%$. The respective figures were $25,73,38$ and $84 \%$ for ESR.

The alveolar type of pneumonia was present in 14 $(48 \%)$ of the PNC cases, in $5(29 \%)$ of the mixed PNCviral cases, and in $8(35 \%)$ of the viral cases. The differences were not statistically significant. The radiological pattern had a poor sensitivity (41\%) and specificity (42\%) in the differentiation between PNC and non-PNC pneumonia. When the presence of an alveolar infiltrate was combined either with elevated CRP or ESR, the diagnostic parameters were not much better. Likewise, the parameters did not perform better when children older than 12 months were analysed separately.

Table 3. - Sensitivity, specificity, and positive and negative predictive value of C-reactive protein concentration (CRP), erythrocyte sedimentation rate (ESR), white blood cell count (WBC) and absolute neutrophil count (ANC) in differentiating pneumococcal (PNC) from nonpneumococcal pneumonia

\begin{tabular}{lccccc}
\hline & \multicolumn{5}{c}{ Diagnostic parameters } \\
\cline { 2 - 6 } Parameter & $\begin{array}{c}\text { PNC } \\
\text { present } \\
(\mathrm{n}=46)\end{array}$ & $\begin{array}{c}\text { Sensi- } \\
\text { tivity } \\
\%\end{array}$ & $\begin{array}{c}\text { Specif- } \\
\text { icity } \\
\%\end{array}$ & $\begin{array}{c}\text { PPV } \\
\text { NPV }\end{array}$ & $\%$ \\
\hline $\begin{array}{l}\mathrm{CRP}>60 \mathrm{mg} \cdot \mathrm{L}^{-1} \\
(\mathrm{n}=28)\end{array}$ & 12 & 26 & 83 & 43 & 76 \\
$\begin{array}{l}\mathrm{ESR}>35 \mathrm{~mm} \cdot \mathrm{h}^{-1} \\
(\mathrm{n}=40)\end{array}$ & 15 & 25 & 73 & 38 & 84 \\
$\begin{array}{l}\mathrm{WBC}>15 \times 10^{9} \cdot \mathrm{L}^{-1} \\
(\mathrm{n}=52)\end{array}$ & 15 & 33 & 60 & 29 & 64 \\
$\begin{array}{l}\text { ANC }>10 \times 10^{9} \cdot \mathrm{L}^{-1} \\
(\mathrm{n}=47)\end{array}$ & 13 & 28 & 63 & 28 & 64 \\
$\begin{array}{l}\text { Alveolar infiltrate } \\
(\mathrm{n}=45)\end{array}$ & 19 & 41 & 42 & 42 & 59 \\
\hline
\end{tabular}

PPV: positive predictive value; NPV: negative predictive value.

\section{Discussion}

The nonspecific inflammatory parameters, such as WBC, ANC, CRP and ESR, reflect the severity of the acute phase reaction. In acute infections, they measure the tissue damage caused by microbes. Accordingly, they are expected to be higher in bacterial than in viral infections. In the present study, CRP, ESR and ANC were higher in patients with PNC pneumonia than in those with viral pneumonia; this is in accordance with previous studies comparing bacterial infections, usually diagnosed by cultural methods, with viral infections $[4,5]$. On the other hand, CRP was not elevated, being under $60 \mathrm{mg} \cdot \mathrm{L}^{-1}$, in over half of the cases with PNC aetiology. CRP, WBC and ANC, in particular, are best in detection of septic or bacteraemic infections [16]. In Western countries, however, blood culture is positive in less than $5 \%$ of children with pneumonia [1]. In the present study, blood cultures were prepared for all children with high fever, and all were negative. Thus, the present results suggest that, in fact, the wide variation in nonspecific host indices reflects the wide variation in the invasiveness of $S$. pneumoniae infection and in the severity of pneumonia caused by this microorganism.

The present study is, to our knowledge, the first to evaluate CRP, ESR, WBC or ANC in childhood pneumonia caused by $S$. pneumoniae, when the aetiology has been verified by sensitive serological methods. In a recent study, the bacterial aetiology of acute lower respiratory infection was indicated by antibody assays; no cut-off values for CRP, ESR or WBC, and no combinations of them, were able to differentiate bacterial from viral cases [17]. The aetiological agent was $H$. influenzae, B. catarrhalis or $M$. pneumoniae in $31 \%$ of the cases, and S. pneumoniae in only $12 \%$. In the present study of PNC infections, the nonspecific host response indices performed better. In both studies, the microbial methods were more sensitive than those used previously; therefore, the proportions of PNC infections, including also PNC infections complicating primarily viral cases, were high $[2,14]$. In the present study, the test panel was large, consisting of practically all currently available methods for S. pneumoniae infections. In serological studies, the numbers of positive findings are partly dependent on the extent of the test panel used $[2,18]$. 
The method by which PNC infection was diagnosed (by antigen, antibody or immune complex assays) had no significant influence on the results.

In clinical practice, an alveolar-type infiltration is used to indicate bacterial pneumonia, and an interstitial-type to indicate viral pneumonia, though this has not been confirmed in many studies $[7,8]$. In our recent study, from part of the present material with less serological assays available, an alveolar infiltrate was suggestive of bacterial pneumonia, but interstitial infiltrates were seen both in viral and bacterial cases [19]. In the present study, elevated CRP and ESR, together with serological PNC findings, were associated with an alveolar type of pneumonia, suggesting an association between the alveolar type of infiltration and pneumonia caused by $S$. pneumoniae. On the other hand, the presence of an alveolar infiltrate had a poor sensitivity and specificity in the screening of PNC pneumonia.

Although typically low, WBC, CRP and ESR values have also been observed to rise in viral respiratory infections, especially in influenza $\mathrm{A}$ and adenoviral infections [20]. In agreement with this observation, the ranges of CRP, ESR, WBC and ANC were wide in the viral infections of the present study; the upper limits of $95 \%$ CIs were as high as: $60 \mathrm{mg} \cdot \mathrm{L}^{-1}$; ERS $35 \mathrm{~mm} \cdot \mathrm{h}^{-1}$; and WBC $15 \times 10^{9}$ cells $\cdot \mathrm{L}^{-1}$. There were no influenza cases, and adenoviral infections were rare. Thus, the most likely explanation for the elevated values in viral infections is secondary bacterial involvement, though not always demonstrable by antibody methods, especially in young children $[14,21]$. Based on the present and previous serological studies, mixed infections are common in children with respiratory syndromes [2, 3, 22].

In the present study, CRP and ESR were useful for the screening of PNC pneumonia. Based on previous experience, CRP seems to be more suitable than ESR for routine clinical practice $[5,16,20]$. The present results suggest a good specificity for the CRP concentration of $60 \mathrm{mg} \cdot \mathrm{L}^{-1}$ as the screening limit. In many studies, lower limits, such as 20 or $40 \mathrm{mg} \cdot \mathrm{L}^{-1}$, have been suggested $[4,5]$. The advantage of CRP over ESR is its rapid rise, less than $24 \mathrm{~h}$ from the beginning of an invasive infection [4]. The rise in WBC or ANC may be even more rapid, though not as constant as the rise in CRP $[6,23]$.

The assumption that a significant antibody response, or the presence of circulating immune complexes in significant amounts indicates a role of $S$. pneumoniae in the infection, is critical to the conclusions of the present study. The methods have been validated in healthy children; antibody responses to PNC C-PS or CPS antigens were seen in $<1 \%$ [3], to a PNL antigen in $<3 \%$ [14], and circulating PNC immune complexes were present in about 1\% [15]. Despite this, we do not know the clinical significance of PNC infections indicated by serological assays, especially if the nonspecific host response indices are low, or the clinical signs resemble more viral than bacterial infection.

The diagnosis of PNC pneumonia is difficult, and the difficulties are greatest when diagnosing the cases in infants. The clinical symptoms and signs of pneumonia may be confusing, infants have weak serological responses $[12,13]$, and even radiological diagnosis is difficult at that age [24]. Moreover, infants have lower responses than older children in nonspecific host response parameters $[9,10]$, as seen in the present study. In addition, mixed viral-bacterial infections are common in infants, and $S$. pneumoniae is the most common bacterial pathogen $[2,3]$. Thus, the demonstration of viral infection, e.g. by rapid antigen detection techniques, does not rule out concomitant PNC aetiology. The present results stress the importance of clinical examination and individual judgement made by experienced doctors, particularly if pneumonia is suspected in an infant.

In conclusion, C-reactive protein and erythrocyte sedimentation rate have limited capacity to differentiate between pneumococcal and viral pneumonia. Nowadays, as a consequence of effective vaccination against $H$. influenzae type b [25], S. pneumoniae is the only significant bacterial cause of community-acquired pneumonia in normally healthy children before school age in our country. In school-aged children, M. pneumoniae and $C$. pneumoniae are equally, or even more important than S. pneumoniae [26, 27]. Pneumonia, when suspected to be of bacterial origin, should be treated with antibiotics [27]. Elevated values of C-reactive protein or erythrocyte sedimentation rate offer some evidence for bacterial aetiology in cases of pneumonia, but low values do not rule it out. C-reactive protein is recommended as the first-line method, and the value of 60 $\mathrm{mg} \cdot \mathrm{L}^{-1}$ as the screening limit.

\section{References}

1. Isaacs D. Problems in determining the etiology of community-acquired childhood pneumonia. Pediatr Infect Dis J 1989; 8: 143-148.

2. Korppi M, Heiskanen-Kosma T, Jalonen E, et al. Aetiology of community-acquired pneumonia in children treated in hospital. Eur J Pediatr 1993; 152: 24-30.

3. Korppi M, Leinonen M, Mäkelä PH, Launiala K. Bacterial co-infection in children hospitalized with respiratory syncytial virus infections. Pediatr Infect Dis J 1989; 8: 687-692.

4. Peltola H. C-reactive protein in rapid differentiation of acute epiglottitis from spasmodic croup and acute laryngotracheitis; a preliminary report. J Pediatr 1983; 102: 713-715.

5. Putto A, Ruuskanen O, Meurman O, et al. C-reactive protein in the evaluation of febrile illness. Arch Dis Child 1986; 61: 24-29.

6. Crain E, Shelov S. Febrile infants: predictors of bacteremia. J Pediatr 1982; 101: 686-689.

7. Grossman L, Caplan C. Clinical, laboratory and radiological information in the diagnosis of pneumonia in children. Ann Emerg Med 1988; 17: 43-46.

8. Swischuk L, Hayden C Jr. Viral vs bacterial pulmonary infections in children: is roentgenographic differentiation possible?. Pediatr Radiol 1986; 16: 278-284.

9. Korppi M, Kröger L. C-reactive protein in viral and bacterial respiratory infection in children. Scand J Infect Dis 1992; 25: 207-213.

10. Korppi M, Kröger L, Laitinen M. White blood cell and differential counts in acute viral and bacterial respiratory infections in children. Scand J Infect Dis 1993; 25: 435-440.

11. Leinonen M, Syrjälä H, Jalonen E, Kujala P, Herva E. Demonstration of pneumolysin antibodies in circulating 
immune complexes: a new diagnostic method for pneumococcal pneumonia. Serodiagn Immunother Infect Dis 1990; 4: 451-458.

12. Koskela M. Serum antibodies to pneumococcal C-polysaccharide in children: a response to acute otitis media or to vaccination. Pediatr Infect Dis J 1987; 6: 519-526.

13. Koskela M, Leinonen M, Häivä VM, Timonen M, Mäkelä $\mathrm{PH}$. First and second dose antibody responses to pneumococcal polysaccharide vaccine in infants. Pediatr Infect Dis J 1986; 5: 45-50.

14. Nohynek H, Eskola J, Kleemola M, Jalonen E, Saikku $\mathrm{P}$, Leinonen $\mathrm{M}$. The role of bacterial antibody assays in diagnosis of acute lower respiratory tract infection in children. Pediatr Infect Dis J 1995; 14: 478-484.

15. Korppi M, Leinonen M. Pneumococcal pneumonia in children; new data from circulating immune complexes (Letter). Eur J Pediatr 1997; (in press).

16. Peltola H, Jaakkola M. Serious bacterial infections: Creactive protein as a serial index of severity. Clin Pediatr 1988; 27: 532-537.

17. Nohynek H, Valkeila E, Leinonen M, Eskola J. Erythrocyte sedimentation rate, white blood cell count and serum C-reactive protein in assessing the etiologic diagnosis of acute lower respiratory infections in children. Pediatr Infect Dis J 1995; 14: 484-490.

18. Korppi M, Koskela M, Jalonen E, Leinonen M. Serologically indicated pneumococcal respiratory infection in children. Scand J Infect Dis 1992; 24: 437-443.

19. Korppi M, Kiekara O, Heiskanen-Kosma T, Soimakallio
S. Comparison of radiological findings and microbial aetiology of pneumonia in children. Acta Paediatr 1993; 81: $360-363$

20. Ruuskanen O, Putto A, Sarkkinen H, Meurman O, Irjala K. C-reactive protein in respiratory virus infection. $J$ Pediatr 1988; 113: 641-646.

21. Korppi M, Heiskanen-Kosma T, Leinonen M, Halonen P. Antigen and antibody assays in the aetiological diagnosis of respiratory infections in children. Acta Paediatr 1993; 82: 137-141.

22. Claesson B, Trollfors B, Brolin I, et al. Etiology of community-acquired pneumonia in children based on antibody responses to bacterial and viral antigens. Pediatr Infect Dis J 1989; 8: 856-861.

23. Bonadio W. Evaluation and management of serious bacterial infections in the febrile young infant. Pediatr Infect Dis J 1990; 9: 905-912.

24. Kiekara O, Korppi M, Tanska S, Soimakallio S. Radiological diagnosis of pneumonia in children. Ann Med 1996; 28: 69-72.

25. Eskola J, Käyhty H, Takala A, et al. A randomized, prospective field trial of a conjugate vaccine in the protection of infants and young children against invasive Haemophilus influenzae type b disease. $N$ Engl J Med 1990; 323: 1381-1387.

26. Saikku P. The epidemiology and significance of Chlamydia pneumoniae. J Infect 1992; 25 (Suppl. 1): 27-34.

27. Anonymous. Pneumonia in childhood (Editorial). Lancet 1988; i: 741-743. 